Cornelius Ruhs, E., O. P. Love, L. Drainville, and F. Vézina. 2021. No common pesticides detected in snow buntings utilizing a farmland landscape in eastern Québec. Avian Conservation and Ecology 16(2):26. https://doi.org/10.5751/ACE-01979-160226

Copyright (C) 2021 by the author(s). Published here under license by the Resilience Alliance.

\title{
No common pesticides detected in snow buntings utilizing a farmland landscape in eastern Québec
}

\author{
Emily Cornelius Ruhs ${ }^{1,2}$, Oliver P. Love ${ }^{3}$, Louis Drainville ${ }^{4}$ and François Vézina ${ }^{1}$ \\ ${ }^{1}$ Université du Quebéc à Rimouski, Département de Biologie, Chimie et Géographie, ${ }^{2}$ University of Chicago, Department of \\ Ecology and Evolution, ${ }^{3}$ University of Windsor, Department of Integrative Biology, ${ }^{4}$ Terre-Eau Inc.
}

\begin{abstract}
Many species of migratory birds are declining worldwide, including throughout North America. Some of the most cited causes of decline are linked to climate change, urbanization, and growth in agriculture. Across eastern Canada, a number of insecticides and herbicides are commonly sprayed before and during the grain growing season to control pests and foliage competitors. During wintering and migration, a declining Arctic-breeding songbird, the snow bunting (Plectrophenax nivalis), utilizes open farmlands of southern Canada; therefore, this could be a period when the species is most exposed to these pesticides. We tested snow bunting tissues (blood and liver) for the 4 pesticides most commonly used in grain agriculture in Canada: atrazine, chlothianidin, imidacloprid, and glyphosate, as well as a glyphosate derivative (aminomethylphosphic acid, AMPA). Although this species is thought to forage in grain fields during autumn through spring, we found no detectable traces of any of the five substances. Wintering buntings may either not be exposed to these pesticides during their presence in agriculture fields or, given the rapid turnover of these pesticides in the blood and tissues, be exposed to doses below detection level in samples.
\end{abstract}

\section{Aucun pesticide commun détecté chez les Plectrophanes des neiges qui fréquentent des milieux agricoles de l'Est du Québec}

RÉSUMÉ. De nombreuses espèces d'oiseaux migrateurs sont en baisse dans le monde entier, y compris en Amérique du Nord. Certaines des causes les plus citées pour expliquer cette baisse sont liées aux changements climatiques, à l'urbanisation et à l'expansion de l'agriculture. Dans l'Est du Canada, des insecticides et des herbicides sont couramment pulvérisés avant et pendant la saison de croissance des céréales pour lutter contre les parasites et les plantes compétitrices. Durant l'hivernage et la migration, le Plectrophane des neiges (Plectrophenax nivalis), oiseau chanteur en diminution qui niche dans l'Arctique, fréquente les terres agricoles du sud du Canada; par conséquent, ces périodes pourraient être celles où l'espèce est la plus exposée à ces pesticides. Nous avons testé certains tissus du plectrophane (sang et foie) pour les 4 pesticides les plus couramment utilisés dans l'agriculture céréalière au Canada : l'atrazine, la chlothianidine, l'imidaclopride et le glyphosate, ainsi qu'un dérivé du glyphosate (l'acide aminométhylphosphonique, AMPA). Bien que l'on pense que cette espèce se nourrisse dans les champs de céréales de l'automne au printemps, nous n'avons trouvé aucune trace détectable de l'une de ces cinq substances. Les plectrophanes hivernant peuvent soit ne pas être exposés à ces pesticides lorsqu'ils sont présents dans les champs agricoles, soit être exposés à des doses inférieures au niveau de détection dans les échantillons étant donné la dégradation rapide de ces pesticides dans le sang et les tissus.

Key Words: Agriculture, atrazine, clothianidin, glyphosate, grain, imidacloprid, snow bunting

\section{INTRODUCTION}

In Canada, the provinces of Ontario and Québec alone account for $91.9 \%$ of total corn production (Hamel and Dorff 2014). Across this crop type, regardless of geographic location, similar insecticides and herbicides are sprayed during the growing season (summer to early fall) to control pests and foliage competitors, respectively (Environment, Energy and Transportation Statistics Division 2015). A review of practices within the agriculture industry is ongoing to determine the biological significance of pesticide exposure on wildlife (Dion 2018, Langlois 2018); however, specific effects of these chemicals on birds, especially following chronic exposure, is generally unknown (but see Evans and Batty 1986, Wilhelms et al. 2006, Mineau and Palmer 2013, Gibbons et al. 2015, McGee et al. 2018). Some pesticides, like neonicotinoids (e.g. imidacloprid and clothianidin), atrazine, glyphosate, and glyphosate derivatives, have long-half lives in soil
(Wilhelms et al. 2006, Battaglin et al. 2009, Hallmann et al. 2014). For example, imidacloprid has a field dissipation half-life of 26.5 to 229 days (Bacey n.d.), clothianidin is field persistent with a half-life from 56.4 to 1155 days (EPA 2005, Bonmatin et al. 2015) and glyphosate a half-life of 2-197 days (mean 47 days; WHO 1994, Giesey et al. 2000, Vencill 2002). Atrazine has a soil halflife of 35-75 days (Vogue et al. 1994, Workman et al. 1995); however, it has been found in the environment years after application (Jablonowski et al. 2010, Jablonowsi et al. 2011). Therefore, it is possible that birds could still be exposed long after the growing season, like during the wintering period when birds utilize agricultural fields.

Some of the most cited causes of declining avian populations are linked to climate change, urbanization, and agriculture intensification (Partners in Flight Landbird Conservation Plan 
2016). Growth in the agriculture sector undoubtedly leads to expansion of pesticide use and mounting evidence shows support for neonicotinoid toxicity in birds (Hallmann et al. 2014). It has also been suggested that these toxic effects are cumulative when birds are exposed chronically, even at small biologically relevant levels (Eng et al. 2017). For example, white-crowned sparrows (Zonotrichia leucophrys) gavaged with doses of imidacloprid $(\sim 0.2$ treated corn seeds) over 3 days showed a decline in fat, body mass, and significant impairment in migratory orientation (Eng et al. 2017). Sparrows given chlorpyrifos also had impaired migratory orientation but showed no changes in body composition (Eng et al. 2017). Further, analysis of long-term datasets in The Netherlands revealed that local bird populations declined by $3.5 \%$ annually in areas where imidacloprid was used at concentrations $>20 \mathrm{ng} \mathrm{liter}^{-1}$ (in Canada typical application rates are 50-320 g $\mathrm{ha}^{-1}, 240 \mathrm{~g}$ liter ${ }^{-1}$ imidacloprid for formulation Admire 240F; CCME 2007, Pest Management Regulatory Agency 2005, Hallmann et al. 2014). There have also been reported negative effects of atrazine on sexual maturation and food intake in Japanese quail (Wilhelms et al. 2006); and, similarly, of glyphosate on the breeding ecology of many marsh-dwelling avian species (Linz et al. 1996). Interestingly, neonicotinoid residues (clothianidin and thiamethoxam) were detected in wild turkeys (Meleagris gallopavo silvestris) sampled in Ontario, Canada during the spring hunting season (MacDonald et al. 2018). However, while we know some details about the impacts of exposure to pesticides, whether or not migrants can be exposed long after the growing season (e.g. winter, migration) is unclear.

The snow bunting (Plectrophenax nivalis) is a small circumpolar Arctic-breeding songbird. In North America, it winters in southern Canada and northern United States. Within centraleastern Canada, snow buntings have a migration route that runs along the St. Lawrence River shore in eastern Québec and up to Greenland (Macdonald et al. 2012, 2016). Snow buntings are cold-specialists (O'Connor et al. 2021, Le Pogam et al. 2021) and are primarily associated with open snow-covered agricultural areas in winter where they feed on a variety of weed seed plants (Gabrielson 1924) and on leftover crops (i.e., grain; Lyon and Montgomerie 2011). As alternative food sources are limited in winter, grain and seeds are their primary food source (Mckinnon et al. 2019) and are most often found in corn stubble fields (Cox 1958, Rosenblatt and Bonter 2018). As such, it has been proposed that these birds could be exposed to agricultural pesticides both in their south range (winter) and as they travel back-and-forth between the wintering and breeding grounds (Lyon and Montgomerie 2011). However, the risk of exposure during these time periods is not entirely clear. As birds become highly hyperphagic and accumulate fat for spring migration (Vincent and Bédard 1976, Le Pogam et al. 2021), it is likely that these agricultural foraging sites are exploited to provide fuel for this arduous migration and also to cope with the cold conditions on arrival to the Arctic. Although snow buntings are not currently threatened globally, recent estimates suggest that snow buntings have declined by over $60 \%$ in some parts of Canada over the last 40 years (Butcher and Niven 2007, Macdonald et al. 2012). Therefore, as this species primarily utilizes agricultural land during winter, it represents an ideal model to examine whether birds foraging in pesticide-treated agricultural landscapes during cold winters may accumulate agricultural pesticides.
In this project, we tested snow bunting tissues (blood and liver) for the four pesticides most commonly used in cereal crops, such as corn, in Canada. We focused on the spring migratory period as this is a time during which the birds accumulate large amounts of body fat for migration through hyperphagia (Le Pogam et al. 2021, Vincent and Bédard 1976, Power 2017) and might therefore be consuming grain-targeted pesticides while migrating along the St. Lawrence shore. The considered pesticides were the four most commonly used in grain agriculture in Canada: atrazine, imidacloprid, chlothianidin, glyphosate, as well as a glyphosate derivative (aminomethylphosphic acid (AMPA)). Our objectives were to (i) assess whether these chemicals were present in tissues that represent short-term (blood) and longer-term exposure (liver) to these pesticides and (ii) if so, at what relative concentrations.

\section{METHODS}

The eastern Canadian population of snow buntings spends the winter from western Ontario to eastern Québec before migrating north-eastward following the Gulf of St. Lawrence (Macdonald et al. 2012, 2016). Therefore, birds $(n=10)$ were collected in March 2018 as this corresponds to the period of hyperphagia and premigratory body mass gain in outdoor captive birds (Le Pogam et al. 2021, Vincent and Bédard 1976, Power 2017). The historic range of snow cover during March in Québec can vary but ranged from 72-136 cm depth in March 2017 (data from 2018 unavailable; https://climate.weather.gc.ca/climate_data). Birds were captured in Saint-Joseph-de-Lepage, Québec, Canada (Lat: 48.575779, Long: -68.169576). All birds were captured on the same day (March $14^{\text {th }}$ ) within three hours (9:52 am to $12: 20 \mathrm{pm}$ ). The capture site was an area with an open cornfield and snow cover. Birds were baited for a few days prior to capture using a certified organic corn product which therefore was not contaminated with the pesticides of interest (Fig. 1). Thus, any level of contamination would have to be resulting from previous exposure. Upon capture, a small blood sample ( $<1 \%$ total body weight) was collected. We then transported birds back to the avian research facilities at the Université du Québec à Rimouski where they were euthanized using $\mathrm{CO}_{2}$ asphyxiation. Birds were then dissected to retrieve liver tissue samples. Liver was used because it (1) accumulates toxins and (2) is the primary source for metabolizing toxicants (Klaassen and Watkins 2008). A total of $\sim 5 \mathrm{~g}$ of tissue was required to analyze for imidacloprid, clothianidin, and atrazine; however, another $\sim 5 \mathrm{~g}$ was required for glyphosate and AMPA. As such, only liver samples were tested for glyphosate and AMPA, as there was not enough blood collected to test for all five pesticides. Samples were then stored at $-80^{\circ} \mathrm{C}$ and prepared for shipment and analysis at Brookside laboratories in Ohio, United States. All procedures were approved by the UQAR Animal Care Committee (CPA-72-18-199) and were conducted under a Canadian Wildlife Services scientific permit (SC-75).

\section{Laboratory analysis}

To determine the presence and levels of clothianidin, imidacloprid, and atrazine in samples, each sample was homogenized and weighed into a $50 \mathrm{~mL}$ polypropylene centrifuge tube, recorded to the nearest $0.001 \mathrm{~g}$. Five $\mathrm{mL}$ of water was then added to the tube. Ten $\mathrm{mL}$ of acetonitrile was added to the tube and shaken for 2 minutes. A packet of QuEChERS (Quick, Easy, Cheap, Effective, Rugged, and Safe) salts was added to the tube 
Fig. 1. Snow buntings feeding on organic (pesticide-free) corn bait during the winter in Québec, Canada. Photo by François Vézina.

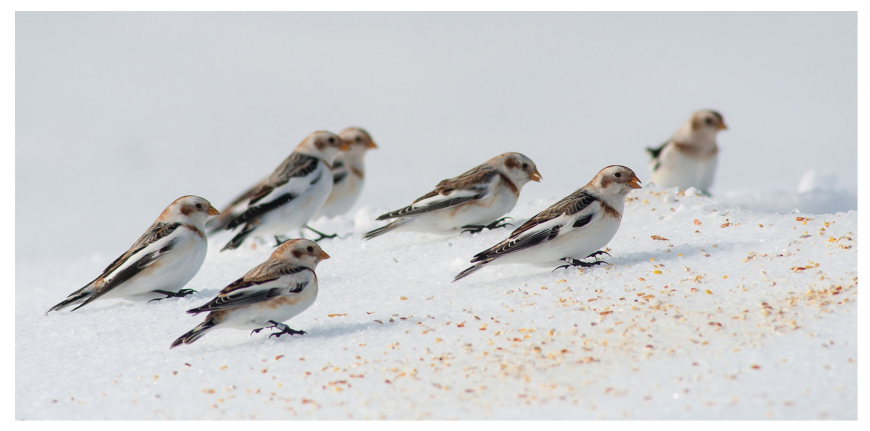

(4 g MgSO4, $1 \mathrm{~g} \mathrm{NaCl}, 0.5 \mathrm{~g}$ disodium citrate, $1 \mathrm{~g}$ trisodium citrate) and shaken for 1 minute. The top layer was then decanted into a cleanup tube containing $1.5 \mathrm{~g} \mathrm{MgSO} 4,0.5 \mathrm{~g} \mathrm{C} 18$, and $0.5 \mathrm{~g}$ PSA. This tube was shaken for 30 seconds and the remaining solvent filtered through a $0.2 \mathrm{um}$ PVDF filter. Four $\mathrm{mL}$ of the extract was blown down under a gentle stream of nitrogen to near dryness and then reconstituted with $1 \mathrm{~mL}$ of methanol and $1 \mathrm{~mL}$ of $0.2 \%$ formic acid in water. If the sample contained precipitates it was filtered again with a 0.2 um PVDF filter into a screw-cap HPLC vial. The sample was then injected into a Thermo TSQ LC-MS/ MS. One parent mass and two daughter masses were monitored for each compound. Matrix-matched calibration standards were produced using chicken liver as the matrix. These analyses had a minimum detection limit of $0.01 \mathrm{mg} / \mathrm{kg}$ for imidacloprid and clothianidin and $0.1 \mathrm{mg} / \mathrm{kg}$ for atrazine.

For glyphosate and AMPA, samples were homogenized and weighed into a $50 \mathrm{~mL}$ polypropylene centrifuge tube, recorded to the nearest $0.001 \mathrm{~g}$. Five $\mathrm{mL}$ of $0.05 \%$ phosphoric acid was then added to the sample. The sample was tumbled end-over-end for 30 minutes. After this time the sample was centrifuged and then passed through a Waters HLB cartridge for cleanup. The collected liquid was diluted a further $5 \mathrm{X}$ and filtered with a 0.2 um PVDF filter into an HPLC vial. The sample was injected into a Waters Alliance 2695 HPLC with Fluorescence Detector and OPA derivatization unit. The limit of quantification was $0.8-2.05 \mathrm{mg} /$ $\mathrm{kg}$ for glyphosate and AMPA.

\section{RESULTS}

There were no detectable amounts of atrazine, clothianidin, or imidacloprid in either the blood or the liver (Table 1). There were also no detectable amounts of glyphosate or aminomethylphosphonic acid (AMPA) in the liver (Table 1).

\section{DISCUSSION}

We found no detectable levels of four of the most commonly used grain pesticides in snow buntings during the spring pre-migratory fattening phase in eastern Québec. There are many possible explanations for this. Chemical degradation rates might prevent birds from becoming contaminated if pesticides and herbicides do not remain in the environment long enough after the last application for the birds to get contaminated (Klaassen and Watkins 2008). To shed light on this, future studies should test corn and grain remnants throughout the course of the year to establish whether these pesticides are still detected months after the application season. Physiological degradation of these chemicals by the animal could also be rapid, bringing contamination levels below detection limits within days after exposure, especially if contamination levels are low (Klaassen and Watkins 2008). For example, imidacloprid was found to degrade to $\sim 22.5 \%$ of starting levels after 25 days (Liu et al. 2011) and $\sim 50 \%$ after 60 days (Mahapatra et al. 2017) of application, depending on environmental factors. Additionally, the absence of pesticides in our birds is likely not simply resulting from the technical capacity to detect them in biological tissues, as our minimal detectable limit $(0.01 \mathrm{mg} / \mathrm{kg}$; atrazine, clothianidin, and imidacloprid) and limit of quantification $(0.8-2.05 \mathrm{mg} / \mathrm{kg}$; glyphosate and AMPA) is well below what has previously been shown to cause toxicity in birds (Fishel 2005).

Table 1. Results from the pesticide testing. There were no detectable quantities of atrazine, clothianidin, imidacloprid, glyphosate, or AMPA in any of the birds sampled. Limit of Quantification (LOQ) is the lowest concentration of analyte in a sample that can be detected, all samples for glyphosate and AMPA were between zero and the LOQ $(0.8-2.05 \mathrm{mg} / \mathrm{kg})$. Note that the minimal detectable limit (MDL) for the tested pesticides is well below concentration levels known to cause health issues in birds.

\begin{tabular}{lcccc}
\hline \hline & $\begin{array}{c}\text { Blood } \\
(\mathrm{mg} / \mathrm{kg})\end{array}$ & $\begin{array}{c}\text { Liver } \\
(\mathrm{mg} / \mathrm{kg})\end{array}$ & Type & MDL or LOQ $^{ \pm}$ \\
\hline Atrazine & ND & ND & Herbicide & 0.01 \\
Clothianidin & ND & ND & Neonicotinoid & 0.01 \\
Imidacloprid & ND & ND & Neonicotinoid & 0.01 \\
Glyphosate & $\cdot$ & ND & Herbicide & $0.8-2.05 \mathrm{mg} / \mathrm{kg}^{ \pm}$ \\
AMPA &. & ND & Herbicide & $0.8-2.05 \mathrm{mg} / \mathrm{kg}^{ \pm}$ \\
\hline
\end{tabular}

indicates an herbicide derivative

Previous studies focusing on the effects of pesticides in birds have been either experimental (Evans and Batty 1986, Mineau and Palmer 2013, Eng et al. 2017) or conducted during the crop growth (and pesticide application) season (Boutin et al. 1999). For example, a study in southern Ontario identified numerous farmland bird species that were at risk of pesticide exposure during the breeding season due to their high occurrence near agricultural landscapes and to the timing of that occurrence with pesticide application (Boutin et al. 1999). Our study aimed to determine whether snow buntings were contaminated during spring, long after the crop growth season. This period could be a very sensitive portion of their annual cycle due to important physiological changes occurring at that time for migration (Le Pogam et al. 2021, Vincent and Bédard 1976, Power 2017), but also due to pesticide contamination, which could increase as premigratory buntings become hyperphagic (Vincent and Bédard 1976, Laplante et al. 2019) and begin fattening for their longdistance flight (LePogam et al. 2021).

While our results are encouraging for this declining species, the lack of detection of these compounds during late winter is not necessarily a sign that these birds are not being exposed during other times of the year or in areas with higher pesticide use (e.g., 
Warner et al. 2019). For example, in eastern Canada, snow buntings are wintering in a gradient of agriculture intensity, from southern Ontario (intense) to Newfoundland (low; Hamel and Dorff 2014) and are faced with increasing pesticide use over time (Agriculture and Agri-Food Canada 2016). Further studies are needed to determine whether snow buntings are contaminated in areas of greater agricultural intensity. More research is also required to define the potential effects of these toxicants and the ecological impacts long after the crop growing season, especially during sensitive life-history stages like pre-migratory fattening. More precisely, future studies should also aim to sample populations that (1) are from other wintering locations where pesticide use is more extensive and (2) across a wider geographical scale varying in their pesticide use intensity.

Since the implementation of this project, both clothianidin and imidacloprid have been restricted, but not for grain crops like corn (PMRA a and b 2019, Environment et Lutte contre les changements climatiques Québec 2021); while glyphosate has been reapproved for the next 15 years. Given that locations for growing grain will increase as temperatures continue to climb and growing seasons get longer (Almaraz et al. 2008, Kucharik and Serbin 2008), understanding the long-lasting effects of pesticide application to wildlife is paramount. Several migratory bird species are declining throughout North America (North American Bird Conservation Initiative Canada 2012) and agricultural expansion could be a factor in this decline, especially in birds associated with open farmland landscapes. Therefore, whether agricultural intensity and pesticide exposure impact population decline is a question of utmost importance.

Responses to this article can be read online at: https://www.ace-eco.org/issues/responses.php/1979

\section{Acknowledgments:}

The authors would like to thank Justine Drolet (UQAR), Jessé Roy-Drainville (UQAR), Caroline Gay (Terre-Eau) and Francis Bordeleau-Martin (Terre-Eau) for their help and support in collection of the samples and for their agriculture advise. We would also like to thank the Centre de formation professionnelle MontJoli-Mitis (CFPMM) for allowing us to catch birds on their property. COMPLIANCE WITH ETHICAL STANDARDS Ethical approval All applicable international, national and institutional guidelines for the care and use of animals were followed. Procedures were institutionally approved by the UQAR Animal Care Committee (CPA-72-18-199). Funding This research was funded through a Natural Sciences and Engineering Research Council of Canada (NSERC) Engage grant awarded to O.P.L. Conflict of interest The authors declare that they have no conflict of interest.

\section{LITERATURE CITED}

Agriculture and Agri-Food Canada. 2016. Pesticides indicator. Governement of Canada. https://agriculture.canada.ca/en/ agriculture-and-environment/agriculture-and-water/pesticides-indicator
Almaraz J. J., F. Mabood, X. Zhou, E. G. Gregorich, and D. L. Smith. 2008. Climate change, weather variability and corn yield at a higher latitude locale: Southwestern Quebec. Climatic Change 88:187-197. https://doi.org/10.1007/s10584-008-9408-y

Bacey J. Environmental fate of imidacloprid. Environmental Monitoring \& Pest Management Branch, Pesticide Regulation branch, California Department of Pesticide Regulation.

Battaglin W. A., K. C. Rice, M. J. Focazio, S. Salmons, and R. X. Barry. 2009. The occurrence of glyphosate, atrazine, and other pesticides in vernal pools and adjacent streams in Washington, DC, Maryland, Iowa, and Wyoming, 2005-2006. Environmental Monitoring and Assessment 155:281-307. https://doi.org/10.1007/ s10661-008-0435-y

Bonmatin J. M., C. Giorio, V. Girolami, D. Goulson, D. P. Kreutzweiser, C. Krupke, M. Liess, E. Long, M. Marzaro, E. A. D. Mitchell, D. A. Noome, N. Simon-Delson, and A. Tapparo. 2015. Environmental fate and exposure; neonicotinoids and fipronil. Environmental Science and Pollution Research 22 (1):35-67. https://doi.org/10.1007/s11356-014-3332-7

Boutin C., K. E. Freemark, and D. A. Kirk. 1999. Farmland birds in southern Ontario: field use, activity patterns and vulnerability to pesticide use. Agriculture, Ecosystems \& Environment 72:239-254. https://doi.org/10.1016/S0167-8809(98)00181-9

Butcher G. S., and D. K. Niven. 2007. Combining data from the Christmas Bird Count and the Breeding Bird Survey to determine the continental status and trends of North America birds. The Journal of Wildlife Management 72(1):44-51.

Canadian Council of Ministers of the Environment (CCME). 2007. Canadian water quality guidelines: imidacloprid. Scientific supporting document. Canadian Council of Ministers of the Environment, Winnipeg.

Cox G. W. 1958. A comparaison of wintering bird populations in three open field types in central Ohio. The Ohio Journal of Science, 58(3):189.

Dion M. 2018. Québec veut encadrer l'usage des pesticides “tueurs d'abeilles." Radio Canada

Eng M. L., B. J. M. Stutchbury, and C. A. Morrissey. 2017. Imidacloprid and chlorpyrifos insecticides impair migratory ability in a seed-eating songbird. Scientific Reports 7:15176. https://doi.org/10.1038/s41598-017-15446-x

Environment et Lutte contre les changements climatiques Québec. 2021. Règlement modifiant le Code de gestion des pesticides; Règlement modifiant le Règlement sur les permis et les certificats pour la vente et l'utilisation des pesticides. Gouvernement du Québec.

Environment, Energy and Transportation Statistics Division. 2015. Canadians and Nature: Fertilizer and Pesticides. Statistics Canada

Environmental Protection Agency. 2005. EFED Registration Chapter for Clothianidin for use on potatoes and grapes as a spray treatment and as a seed treatment for sorghum and cotton. Environmental Risk Branch V, Environmental Fate and Effects Division (7507C). 
Evans D d., M. J. Batty. 1986. Effects of high dietary concentrations of glyphosate (roundup ${ }^{\circledR}$ ) on a species of bird, marsupial and rodent indigenous to Australia. Environmental Toxicology and Chemistry 5:399-401. https://doi.org/10.1002/ etc. 5620050410

Fishel F. M., 2005. Pesticide toxicity profile: Neonicotinoid pesticides (Univ. of Florida, IFAS, Gainesville, FL, 2005); http:// allianceofdelray.com/picture/271neonicotinoid_pesticide_toxicity_profile. pdf. https://doi.org/10.32473/edis-pi117-2005

Gabrielson I. A. 1924. Food habits of some winter bird visitants. United States Department of Agriculture, Washington, D.C. https://doi.org/10.5962/bhl.title.64901

Gibbons D., C. Morrissey, and P. Mineau. 2015. A review of the direct and indirect effects of neonicotinoids and fipronil on vertebrate wildlife. Environmental Science and Pollution Research 22:103-118. https://doi.org/10.1007/s11356-014-3180-5

Giesey J. P., S. Dobson, K. R. Solomon. 2000. Ecotoxicological risk assessment for Roundup herbicide. Reviews of Environmental Contamination and Toxicology 167:35-120. https://doi.org/10.1007/978-1-4612-1156-3_2

Hallmann C. A., R. P. B Foppen, C. A. M van Turnhout, H. de Kroon, and E. Jongejans. 2014. Declines in insectivorous birds are associated with high neonicotinoid concentrations. Nature 511:341. https://doi.org/10.1038/nature13531

Hamel M. A., and E. Dorff. 2014. Corn: Canada's third most valuable crop. Statistics Canada.

Jablonowski N. D., A. Schäffer, P. Burauel. 2010. Still present after all these years: persistence plus potential toxicity raise questions about the use of atrazine. nvironmental Science and Pollution Research 18:328-331. https://doi.org/10.1007/s11356-010-0431y

Jablonowski N. D., G. Hamacher, R. Martinazzo, U. Langen, S. Köppchen, D. Hofmann, P. Buraurel. 2011. Metabolism and persistence of atrazine in several field soils with different atrazine application histories. Journal of Agricultural and Food Chemistry 58:12869-12877. https://doi.org/10.1021/jf103577j

Klaassen C. D., J. B. Watkins. 2008. Casarett and Doull's Toxicoogy: The basic science of poisons, 7th edn. McGraw-Hill, New York

Kucharik C. J., and S. P. Serbin. 2008. Impacts of recent climate change on Wisconsin corn and soybean yield trends. Environmental Research Letters 3:034003. https://doi. org/10.1088/1748-9326/3/3/034003

Laplante M., E. A. McKinnon, O. P. Love, and F. Vézina. 2019. Flexible response to short-term weather in a cold-adapted songbird. Journal of Avian Biology 50(2). https://doi. org/10.1111/jav.01766

Langlois P. February 19, 2018. Les nouvelles règles sur les pesticides applaudies dans l'Est-du-Québec. Radio Canada. https://ici.radio-canada.ca/nouvelle/1084750/abeilles-pesticidesapiculteurs-producteurs-grains

Le Pogam A., R. O'Connor, O. P. Love, M. Petit, L. Régimbald, and F. Vézina. 2021. Coping with the worst of both worlds: phenotypic adjustments for cold acclimatization benefit northward migration and arrival in the cold in an Arctic breeding songbird. Functional Ecology (in press). https://doi.

org/10.1111/1365-2435.13793

Linz G. M., D. C. Blixt, D. L. Bergman, and W. J. Bleier. 1996. Responses of Red-Winged Blackbirds, Yellow-Headed Blackbirds and Marsh Wrens to glyphosate-induced alterations in cattail density. Journal of Field Ornithology 67:167-176

Liu Z., Y. Dai, G. Huang, Y. Gu, J. Ni, H. Wei, and S. Yuan. 2011. Soil microbial degradation of neonicotinoid insecticides imidacloprid, acetamiprid, thiaclopid and imidaclothiz and its effects on the persistence of bioefficiancy against horse bean aphid Aphis craccivora Koch after soil application. Pest Management Science 67:1245-1252. https://doi.org/10.1002/ ps. 2174

Lyon B., and R. Montgomerie. 2011. Snow Bunting (Plectrophenax nivalis). The Birds of North America https://doi. org/10.2173/tbna.198-199.p

Macdonald C. A., K. C. Fraser, H. G. Gilchrist, T. K. Kyser, J. W. Fox, and O. P. Love. 2012. Strong migratory connectivity in a declining Arctic passerine. Animal Migration 1:23-30. https://doi. org/10.2478/ami-2012-0003

Macdonald C. A., E. A. McKinnon, H. G. Gilchrist, and O. P. Love. 2016. Cold tolerance, and not earlier arrival on breeding grounds, explains why males winter further north in an Arcticbreeding songbird. Journal of Avian Biology 47:7-15. https://doi. org/10.1111/jav.00689

Macdonald A. M., C. M. Jardine, P. J. Thomas, and N. M. Nemeth. 2018. Neonicotinoid detection in wild turkeys (Meleagris gallopavo silvestris) in Ontario, Canada. Environmental Science and Pollution Research 25:16254-16260. https://doi. org/10.1007/s11356-018-2093-0

Mahapatra B., T. Adak, N. K. B. Patil, G. C. P. Pandi, G. Basana Gowda, M. Kumar Yadav, S. D. Mohapatra, P. C. Rath, S. Muna, and J. Mayabini. 2017. Effect of abiotic factors on degradation of imidacloprid. Bulletin of Environmental Contamination and Toxicology 99475-480. https://doi.org/10.1007/s00128-017-2159-6

McGee S., M. Whitfield-Aslund, D. Duca, N. Kopysh, T. Dan, L. Knopper, and L. Brewer. 2018. Field evaluation of the potential for avian exposure to clothianidin following the planting of clothianidin-treated corn seed. PeerJ. https://doi.org/10.7717/ peerj. 5880

Mckinnon E.A., M. Laplante, O. P. Love, K. C. Fraser, S. Mackenzie, F. Vézina. 2019. Tracking landscape-scale movements of snow buntings and weather-driven changes in flock composition during the termperate winter. Frontiers in Ecology and Evolution 7:329. https://doi.org/10.3389/fevo.2019.00329

Mineau P and C. Palmer. 2013. The impact of the nation's most widely used insecticides on birds. American Bird Conservancy, USA

North American Bird Conservation Initiative Canada. 2012. The State of Canada's Birds. Environment Canada, Ottawa, Canada

O'Connor R., A. Le Pogam, K. Young, F. Robitaille, E. Choy, O. P. Love, K. Elliott, A. Hargreaves, D. Berteaux, A. Tam, and F. 
Vézina. 2021. Limited heat tolerance in an Arctic passerine: thermoregulatory implications for cold-specialized birds in a rapidly warming world. Ecology and Evolution (in press). https:// doi.org/10.1002/ece3.7141

Partners in Flight Landbird Conservation Plan. 2016. In: Partners in Flight. https://www.partnersinflight.org/resources/the-plan/.

Pest Management Regulatory Agency (PMRA). 2019a. Reevaluation decision, Clothianidin and its associated end-use products: pollinatory re-evaluation. ISSN: 1925-0886

Pest Management Regulatory Agency (PMRA). 2019b. Reevaluation decision, Imidacloprid and its associated end-use products: pollinatory re-evaluation. ISSN: 1925-0886

Power S. 2017. Endogenous regulation of seasonal energetic phenotypes: investigating the hormonal mechanisms of fat gain and muscle growth across avian life-history stages in two Arctic birds. MSc Thesis, University of Windsor, Canada. Electronic Theses and Dissertations. 7389. https://scholar.uwindsor.ca/ etd/7389

Rosenblatt C. J., D. N. Bonter. 2018. Characteristics of fields used by birds in winter in New York. The Wilson Journal of Ornithology 130(4):924-931. https://doi.org/10.1676/1559-4491.130.4.924

Vencill W. K. 2002. Herbicide Handbook, 8th ed. Weed Science Society of America: Lawrence, KS, p 231-234.

Vincent J, J. and Bédard. 1976. Fat reserves in Snow Buntings. Canadian Journal of Zoology 54:1051-1063. https://doi. org/10.1139/z76-119

Warner N. A., K. Sagerup, S. Kristoffersen, D. Herzke, G. W. Gabrielsen, B. J. Jenssen. 2019. Snow buntings (Plectrophenax nivealis) as bio-indicators for exposure differences to legacy and emerging persistent organic pollutants from the Arctic terrestrial environment on Svalbard. Science of the Total Environment 667:638-647. https://doi.org/10.1016/j.scitotenv.2019.02.351

WHO. 1994. Environmental Health Criteria 159, Toxicological Evaluations - Glyphosate; International Programme on Chemical Safety, World Health Organization: Geneva, Switzerland.

Wilhelms K. W., S. A. Cutler, J. A. Proudman, L. L. Anderson, and C. G. Scanes. 2006. Effects of atrazine on sexual maturation in female Japanese quail induced by photostimulation or exogenous gonadotropin. Environmental Toxicology and Chemistry 25:233-240. https://doi.org/10.1897/05-039R.1

Workman S. R., A. D. Ward, N. R. Fausey, and S. E. Nokes. 1995. Atrazine and Alachlor dissipation rates from field experiments. Transactions of the ASAE 38(5):1421-1425. https://doi. org/10.13031/2013.27966 